Final Scientific Report

\title{
Final Scientific Report
}

BARD Project Number: US-4015-07

Date of Submission of the report: 9 December 2011

Project Title: Molecular and anatomical characterization of sweetpotato storage root formation

Investigators

Principal Investigator (PI): Don LaBonte Etan Pressman

\section{Institutions}

Louisiana State University AgCenter ARO, The Volcani Center

Co-Principal Investigator (Co-PI):

Nurit Firon ARO, The Volcani Center

Arthur Villordon Louisiana State University AgCenter

\section{Collaborating Investigators:}

Keywords not appearing in the title and in order of importance. Avoid abbreviations.

Abbreviations commonly used in the report, in alphabetical order:

SR-Storage roots

FR-Fibrous roots

TR-Thick pigmented roots

Budget: IS: $\$ 147,000 \quad$ US: $\$ 148,000 \quad$ Total: $\$ 295,000$

Signature

Principal Investigator
Signature

Authorizing Official, Principal Institution 
Publication Summary (numbers)

\begin{tabular}{|l|c|c|c|c|}
\hline & $\begin{array}{c}\text { Joint } \\
\text { IS/US } \\
\text { authorship }\end{array}$ & $\begin{array}{c}\text { US Authors } \\
\text { only }\end{array}$ & $\begin{array}{c}\text { Israeli } \\
\text { Authors } \\
\text { only }\end{array}$ & Total \\
\hline $\begin{array}{l}\text { Refereed (published, in press, accepted) } \\
\text { BARD support acknowledged }\end{array}$ & 2 & 2 & & 4 \\
\hline Submitted, in review, in preparation & 2 & & & \\
\hline Invited review papers & & & & 1 \\
\hline Book chapters & 1 & & 1 & 1 \\
\hline Books & & & & \\
\hline Master theses & & & 1 & 7 \\
\hline Ph.D. theses & & 6 & 1 & 4 \\
\hline Abstracts & 1 & 2 & & \\
\hline Not refereed (proceedings, reports, etc.) & & & & \\
\hline
\end{tabular}

Postdoctoral Training: List the names and social security/identity numbers of all postdocs who received more than $50 \%$ of their funding by the grant.

Cooperation Summary (numbers)

\begin{tabular}{|l|l|l|l|l|}
\hline & $\begin{array}{c}\text { From US to } \\
\text { Israel }\end{array}$ & $\begin{array}{c}\text { From Israel } \\
\text { to US }\end{array}$ & $\begin{array}{c}\text { Together, } \\
\text { elsewhere }\end{array}$ & Total \\
\hline $\begin{array}{l}\text { Short Visits \& } \\
\text { Meetings }\end{array}$ & 1 & 2 & & 3 \\
\hline $\begin{array}{l}\text { Longer Visits } \\
\text { (Sabbaticals) }\end{array}$ & & & & \\
\hline
\end{tabular}

\section{Description Cooperation:}

Our research group (E. Pressman, N. Firon, A.Villordon and D. LaBonte) met on two occasions in the first year in order to coordinate research activities relating to anatomical characterization of storage root formation and to harmonize methodology to ensure data could be jointly published. Two joint papers were published as well as a joint book chapter, summarizing our data relating to Israeli and US main sweetpotato varieties, indicating that the early adventitious roots represent the future crop and characterizing the anatomical features of an initiating storage root (as compared to a 'feeder' fibrous root). These data serve us now as a tool for identifying storage root inductive (and inhibitory) conditions. Our meeting and e-mail correspondence helped us in planning our second objective which is the identification of genes responsible for storage root and fibrous root development. The approach was to identify 
candidate genes for quantitative PCR based on c-DNA AFLP and 454 cDNA sequence data and genomic data from public databases. The bioinformatics work is being conducted jointly. A third meeting was held in the U.S. in January 2011 to finalize procedures towards developing a root transcriptome identify candidate genes for expression studies, and manuscript development.

Patent Summary (numbers)

\begin{tabular}{|l|c|c|c|c|}
\hline & $\begin{array}{c}\text { Israeli } \\
\text { inventor } \\
\text { only }\end{array}$ & $\begin{array}{c}\text { US inventor } \\
\text { only }\end{array}$ & $\begin{array}{c}\text { Joint } \\
\text { IS/US } \\
\text { inventors }\end{array}$ & Total \\
\hline Submitted & & & & 0 \\
\hline $\begin{array}{l}\text { Issued } \\
\text { (allowed) }\end{array}$ & & & & \\
\hline Licensed & & & & \\
\hline
\end{tabular}




\section{Final Scientific Report}

\section{Abstract}

\section{Original objectives:}

1. Anatomical study of storage root initiation and formation.

2. Induction of storage root formation.

3. Isolation and characterization of genes involved in storage root formation.

a. During the normal course of storage root development.

b. Following stress-induced storage root formation.

Background: Sweetpotato is a high value vegetable crop in Israel and the U.S. and acreage is expanding in both countries and the research herein represents an important backstop to improving quality, consistency, and yield. This research has two broad objectives, both relating to sweetpotato storage root formation.

The first objective is to understand storage root inductive conditions and describe the anatomical and physiological stages of storage root development. Sweetpotato is propagated through vine cuttings. These vine cuttings form adventitious roots, from pre-formed primordiae, at each node underground and it is these small adventitious roots which serve as initials for storage and fibrous (nonstorage) "feeder" roots. What perplexes producers is the tremendous variability in storage roots produced from plant to plant. The marketable root number may vary from none to five per plant. What has intrigued us is the dearth of research on sweetpotato during the early growth period which we hypothesize has a tremendous impact on ultimate consistency and yield. The second objective is to identify genes that change the root physiology towards either a fleshy storage root or a fibrous "feeder" root. Understanding which genes affect the ultimate outcome is central to our research.

Major conclusions: For objective one, we have determined that the majority of adventitious roots that are initiated within 5-7 days after transplanting possess the anatomical features associated with storage root initiation and account for $86 \%$ of storage root count at 65 days after transplanting. These data underscore the importance of optimizing the growing environment during the critical storage root initiation period. Water deprivation during this phenological stage led to substantial reduction in storage root number and yield as determined through growth chamber, greenhouse, and field experiments. Morphological characterization of adventitious roots showed adjustments in root system architecture, expressed as lateral root count and density, in response to water deprivation. For objective two, we generated a transcriptome of storage and lignified (non-storage) adventitious roots. This transcriptome database consists of 55,296 contigs and contains data as regards to differential expression between initiating and lignified adventitious roots. The molecular data provide evidence that a key regulatory mechanism in storage root initiation involves the switch between lignin biosynthesis and cell division and starch accumulation. We extended this research to identify genes upregulated in adventitious roots under drought stress. A subset of these genes was expressed in salt stressed plants.

Achievements: Our research demonstrates that lack of water during plant establishment irrevocably reduces yield. Growers have listened and have changed production practices. The transcriptome developed is a tremendous resource for understanding genes involved in storage root formation and stress response. 


\section{Final Scientific Report}

\section{Achievements - significance}

1. Literature review: The research group undertook an extensive review of the current literature relating to storage root formation in 2008. The outcome was a collaborative book chapter in a 2009 Springer-Verlag book release,"The Sweet Potato". Data on gene expression in fibrous and storage roots was included.

2. Identifying root initials forming storage roots: We conducted greenhouse, growth chamber, and field studies on storage root development. Our combined findings showed that the first adventitious roots marked and tracked after 5-7 days of growth possessed the anatomical features associated with storage root development. In addition and in accordance with these findings, up to $85 \%$ of "Beauregard" (an important US variety) and "Georgia Jet" (the main Israeli variety) storage roots (after 60 days growth) were traced back to these 5-7 day old adventitious roots. Agricultural and economic impact: These results represent a major deviation from previous published work which surmised that storage root development occurred much later. On a practical basis, this research showed that these early adventitious roots represent the future crop. Anything we can do to sway a greater proportion of these adventitious roots towards becoming a fleshy storage root, the greater the yield. These results were published as a joint publication in HortScience (2009).

3. Environmental factors effecting storage root development: Our interest was to target environmental variables like moisture and temperature on storage root formation. Drought stress: One of the most important abiotic factors is the availability of soil moisture at early stages of plant growth. Greenhouse studies showed that soil moisture content is correlated with storage root formation. The less water available, the more adventitious roots form into fibrous roots. Two replications of a study showed that storage root number was significantly lower (up to twice as much) in transplants with a five and 10 day delay in watering. Field studies using rain shelters to control moisture were used to understand the phenological stages associated with transplant establishment, storage root initiation, and initial storage root bulking. The identification of these growth stages is important in interpreting molecular data related to storage root initiation events. Temperature stress: These same field studies showed that temperature levels of $39^{\circ} \mathrm{C}$ in the upper $5 \mathrm{~cm}$ of soil 


\section{Final Scientific Report}

inhibited storage root formation in this upper soil horizon. Agricultural and economic impact: Our work demonstrated that a deficit in soil moisture resulted in the failure or delay in the onset of storage root initiation. Transplants adjust to the interactive effects of soil moisture and temperature variability by initiating storage roots in nodes where soil-related variables (water and temperature) are not limiting. Producers have been alerted that water deficits and elevated temperatures at transplanting will irreparably reduce yield. Growers have heeded these warnings in the U.S. and changed production practices.

4. Growing degree day characterization: An extension of understanding storage root formation in the field is through a growing degree day model. Results showed similar trends to what occurs in the greenhouse; however, fewer growing degree days are required to reach a similar anatomical stage. A joint manuscript was submitted and published in Scientia Horticultura. A referred journal article was published in HortScience which describes the phenoogy-based decision-theoretic model for sweetpotatato yield outcome. Agricultural and economic impact: This work integrates significant new information related to the timing of storage root initiation.

5. Effect of simulated drought on root system architecture attributes: After it was determined that simulated drought stress reduced overall adventitious root count, the influence of drought stress on roots was measured. Greenhouse studies showed a driect relationship between drought stress and reduced lateral root density as quantified through WinRhizo (Regents Instruments) root scanning software. The reduction was related to an increase in stele lignification, i.e., non-storage roots. Agricultural and economic impact: This data shows that roots adapt to a different morphology under drought stress.

6. Root transcriptome database: The goal of this study was to make a comparative genomic analysis of sequences derived from initiated (early developing) storage roots and fibrous roots and to annotate sequences found in sweetpotato. A root transcriptome was generated containing 55,296 contigs and obtained data as regard to differentially expressed contigs between initiating and lignifed adventitious roots. Approximately 80,000 are new. Agricultural and economic impact: This represents the first unified database presenting the functional annotation and characterization of genes relating to cellular processes and metabolic pathways in sweetpotato. 


\section{Final Scientific Report}

7. Differential expression studies comparing storage roots and fibrous root: The molecular data provide evidence that a key regulatory mechanism in storage root initiation involves the switch between lignin biosynthesis and cell division and starch accumulation. Our findings showed that part of the regulatory network that is presumed to be involved in storage root initiation include genes coding for cyclin Dlike and cyclin-dependent kinases (cell division regulation), class I knotted-like genes (regulate meristems) are up regulated in initiating storage roots. The lignin biosynthesis pathway was shown to be highly down-regulated in initiating storage roots and up regulated in lignified adventitious roots. Agricultural and economic impact: Molecular work can be undertaken to show that storage root initiation signals are perceived at the adventitious root level to help explain the variability in storage root initiation in response to soil moisture and temperature variability.

8. Molecular and adaptive response to drought and salt stress. Fifteen genes upregulated in adventitious roots subjected to delayed watering were identified as candidate genes based on root transcriptome data. Nine of the genes were upregulated under drought stress and three were down regulated. Upregulated genes included a homeodomain leucine zipper family gene, a cytokinin response factor, a calmodulin binding protein, an ethylene responsive binding protein, and a cytokinin pathway gene. KNOX and BELL family genes and an ABA responsive element were also modulated under external environmental stimuli. A parallele study showed two of these genes were also upregulated in roots of 15 day old plants subjected to salt stress. The underlying mechanisms (drought and salt stress) appear similar. 


\section{Final Scientific Report}

\section{Details of Cooperation}

Our research group (E. Pressman, N. Firon, A.Villordon and D. LaBonte) has met on two occasions. The first was 18-20 January 2008 in Asheville, North Carolina. N. Firon met with A. Villordon and D. LaBonte to coordinate research activities relating to anatomical characterization of storage root formation. The objective was to harmonize methodology to ensure data could be jointly published. There was also a special symposium at the "National Sweetpotato Colloborators Group" on storage root initiation organized by A. Villordon. N. Firon and D. LaBonte each gave a presentation to the congress. Other invited speakers from Japan (M. Tanaka) and Korea (J. Bae) presented on gene expression in storage roots.

A second meeting in Israel was hosted by N. Firon and E. Pressman from 27 October to 1 November 2008. The objectives were threefold. First, extensive discussions were held to develop an effective plan to examine environmental factors which may impact storage root formation. These efforts are both practical, i.e., developing strategies for producers to optimize storage root formation, and theoretical, i.e., a need to identify critical environmental cues which "turn on" and "turn off" storage root formation. Our research targeting the critical genes activated or inactivated in roots requires us to have durable treatments which have predictable outcomes - adventitious roots which produce storage roots or adventitious roots which produce fibrous roots. The earlier during development we can assess gene expression, the more likely we will identify key genes responsible. A second objective was to plan our respective investigative strategies towards identifying genes responsible for storage root and fibrous root development. The approach is based on our c-DNA AFLP and the 454 cDNA sequencing data and public genomic databases. The Israeli group will supplement cDNA AFLP generated data with a comprehensive profiling of the gene transcript populations in fibrous and initiating storage roots using the 454 sequencing. The intent in the U.S. is to develop a new generation microarray based on this sequence data. We now have the sequence data prepared for making an array, but the results will post-date this final report. A third objective was to provide Israeli growers information regarding our BARD based sweetpotato research, production practices in the U.S. and current variety outlook in the U.S. during a morning producer seminar 


\section{Final Scientific Report}

series. A number of producers were visited on-farm over several days by both the US and Israeli partners. Our understanding of grower needs was reinforced by these visits. A seminar series at the Volcani Center for researchers was also conducted. A visit to Professor Roni Aloni at Tel-Aviv University finalized our visit. Professor Aloni presented a lecture on his interpretations of developmental events triggering storage root formation.

The group in 2009 relied on frequent emails to continuously present updates on research and review and revise manuscripts for publication. The group continued to communicate findings in 2010 through emails. A meeting was held in January 2011 to review progress to date and to present research findings at the National Sweet Potato Collaborators Group and to finalize strategy as the grant nears completion, and identify research results suitable for publication.

\section{a. Producer outreach}

In 2008 we conducted a seminar series in Israel for growers to better inform them of current production practices in the U.S. and the BARD research. We also learned more about Israeli operations by on-farm visits and expanded our networking to involve extension specialists. We clearly felt there were several areas of common interest beyond the scope of the grant. Both sets of growers (U.S. and Israeli) need greater control of postharvest loss, and secondly, varieties may exist which could store longer in Israel to enable year round market sales. Strategies were discussed to screen U.S. breeding lines in Israel for suitability. Phytosanitary/quarantine issues were raised and this is being addressed with appropriate agencies in Israel to enable importation of true seed. This seems to have a reached a positive outcome. Growers in Israel have not come to consensus on how to proceed. BARD based data was presented to U.S. producers in 2009 stressing the importance of adequate soil moisture at planting. U.S. based growers are heeding our recommendations. This communication continued at several grower meetings in Louisiana in 2010 and 2011.

\section{List of Publications:}

\section{Book chapter}




\section{Final Scientific Report}

N. Firon, Y. Kfir, and E. Pressman, D. LaBonte, A. Villordon and C. McGregor. 2009. Storage root formation and development. In: (G. Loebenstein and G. Thottappilly) The Sweet Potato. Springer Verlag Press.

\section{Refereed}

Villordon, A., D. La Bonte, N. Firon, Y.Kfir, E. Pressman, and A. Schwartz. 2009. Characterization of adventitious root development in sweetpotato. HortScience 44:651-655.

Villordon, A., D. LaBonte, and N. Firon 2009. Development of a simple thermal time method for describing the onset of morpho-anatomical features related to sweetpotato storage root formation. Scientia Horticulturae 121:374-377.

Villordon, A., J. Solis, C. Clark, and D. Labonte. 2010. Development of a prototype Bayesian network model representing the relationship between fresh market yield and some agroclimatic variables known to influence storage root initiation in sweetpotato. HortScience 45:1167-1177.

Villordon, A, D. LaBonte, J. Solis. 2011. Using a scanner-based minirhizotron system to characterize sweetpotato adventitious root development during the initial storage root bulking stage. HortScience 46:513-517.

\section{Non-refereed}

Firon, N., Kfir, Y., Schwartz, A., Villordon, A., Labonte, D., Althan, L., Shaked, R. and Pressman., E. (2008). The first thirty days after planting - a crucial time determining sweetpotato crop values. Sadeh Veyarak, May issue. (in Hebrew).

Firon, N., Pressman, E., Shemer, T., Amichai, M., Kfir, Y., Cohen, S., Althan, L. and Shaked, R. (2009). The effect of salty water irrigation on storage root development in sweetpotato. Yevul See, November issue:40-43 (in Hebrew). 


\section{Final Scientific Report}

Thesis

Kfir Y (2010) Anatomical, biochemical and molecular study of sweet potato storage root formation in M.Sc.Thesis, submitted to the Faculty of Agriculture and Food and Environmental Quality, Hebrew University, Jerusalem, Israel.

\section{Abstracts}

Firon, N. Z. Shemer, Y. Kfir, M. Amichai, E. Pressman, L. Althan. 2011. The effect of salty water irrigation on sweetpotato storage root formation. HortScience (in press).

Villordon, A., J. Solis, D. LaBonte, C. Clark, and R. Sheffield. 2011. Further calibration and validation of a Bayesian belief network model representing the relationship between fresh market yield and agroclimatic variables known to influence storage root initiation in 'Beauregard' sweetpotato. HortScience (in press).

Villordon, A. J. Solis, and D. LaBonte. 2011. Preliminary experience using a minirhizotron-based system for characterizing adventitious root development during the storage root initiation period. HortScience (in press).

Villordon, A., J. Solis, D. LaBonte, and C. Clark. 2010. The Bayesian choice: towards a decision-theoretic approach of determining irrigation frequency and amount in sweetpotato production. HortScience 45:507.

Solis, J., D. LaBonte, and A. Villordon. 2009. The effect of water on storage root initiation in sweetpotato. Proceedings: International Society for Tropical Root Crops. Pg. 76. Lima, Peru.

Solis, J., R. Rodriquez, and D. LaBonte. 2009. In silico prediction and characterization of micro RNAs from sweetpotato [Ipomoea batatas (L.) Lam.]. Proceedings: International Society for Tropical Root Crops. Pg. 68. Lima, Peru. 


\section{Final Scientific Report}

Villordon, A., D. Labonte, and J. Solis. 2009. Observations of adventitious root

initiation and storage root formation under field conditions. HortScience 44:3. American Society for Horticultural Science Annual Meeting, St. Louis, Missouri.

\section{Presentations}

"The effect of salty water irrigation on sweetpotato storage root formation". National Sweet Potato Collaborators Group. January 2011.

"Further calibration and validation of a Bayesian belief network model representing the relationship between fresh market yield and agroclimatic variables known to influence storage root initiation in 'Beauregard' sweetpotato". National Sweet Potato Collaborators Group. January 2011.

"Preliminary experience using a minirhizotron-based system for characterizing adventitious root development during the storage root initiation period. National Sweet Potato Collaborators Group. January 2011"

"Research update: verification of storage root initiation under field conditions" Louisiana Sweet Potato Association Annual Meeting, Oak Grove, Louisiana. 7 Jan 2009

"Storage root initiation and determination of potential yield: what we know, think we know, and don't yet know." US Sweet Potato Council Convention, Baton Rouge, Louisiana. 26 Jan. 2009

Observations of adventitious root initiation and storage root formation under field conditions. National Sweet Potato Collaborators Meeting, Atlanta, Georgia, 31 Jan. 2009 


\section{Final Scientific Report}

"A review: The first 32 days after transplanting" South Louisiana. Production and Advisory Meeting, Avoyelles Parish, Louisiana. 4 Feb 2009

"Feeling the pulse of your crop: estimating yield and harvest time and looking for signs of trouble. Pre-Harvest Sweet Potato Workshop, Winnsboro, Louisiana. 11 Aug 2009

"Using sweetpotato crop phenology to optimize crop management practices". Presentation to Borlaug Fellowship Program participants, Chase, Louisiana. 17 September 2009

"Observations of adventitious root initiation and storage root formation under field conditions" American Society for Horticultural Science Annual Meeting, St. Louis, Missouri. July 2009.

"The effect of water on storage root initiation in sweetpotato" International Society for Tropical Root Crops. Pg. 76. Lima, Peru.

"In silico prediction and characterization of micro RNAs from sweetpotato [Ipomoea batatas (L.) Lam.]" International Society for Tropical Root Crops. Pg. 68. Lima, Peru.

\section{Appendix}

Table of contents:

\section{Published papers}

N. Firon, Y. Kfir, and E. Pressman, D. LaBonte, A. Villordon and C. McGregor. 2009. Storage root formation and development. In: (G. Loebenstein and G. Thottappilly) The Sweet Potato. Springer Verlag Press. 


\section{Final Scientific Report}

A. Villordon, A., D. La Bonte, N. Firon, Y.Kfir, E. Pressman, and A. Schwartz. 2009. Characterization of adventitious root development in sweetpotato. HortScience 44:651-655.

Villordon, A., D. LaBonte, and N. Firon 2009. Development of a simple thermal time method for describing the onset of morpho-anatomical features related to sweetpotato storage root formation. Scientia Horticulturae 121:374-377.

Villordon, A., J. Solis, C. Clark, and D. Labonte. 2010. Development of a prototype Bayesian network model representing the relationship between fresh market yield and some agroclimatic variables known to influence storage root initiation in sweetpotato. HortScience 45:1167-1177.

Villordon, A, D. LaBonte, J. Solis. 2011. Using a scanner-based minirhizotron system to characterize sweetpotato adventitious root development during the initial storage root bulking stage. HortScience 46:513-517.

\section{Unpublished data}

Data on root transcriptome and differential gene expression between initiating and fibrous roots. Data for joint publication.

Data on storage root formation and gene expression under drought stress 